\title{
The Effectiveness of the RAP (Read, Ask, Put) Strategy to Improve Functional Reading Comprehension for Students with Mild Intellectual Disabilities
}

\author{
Firsta A. Sukmawan ${ }^{\mathrm{a}}$ and Rose Mini A. Prianto $\mathrm{b}^{\mathrm{*}}$ \\ ${ }^{a}$ Faculty of Psychology, Universitas Indonesia, Depok, Indonesia; ${ }^{b}$ Educational Psychology \\ Department, Faculty of Psychology, Universitas of Indonesia, Depok, Indonesia \\ *Corresponding Author: \\ Rose Mini A. Prianto \\ Educational Psychology Department \\ Faculty of Psychology, Universitas Indonesia \\ Jl. Lkr. Kampus Raya, Depok, Jawa Barat \\ Indonesia, 16424 \\ Tel.: +62 217270004 \\ E-mail address: romy.prianto@gmail.com
}




\title{
The Effectiveness of the RAP (Read, Ask, Put) Strategy to Improve Functional Reading Comprehension for Students with Mild Intellectual Disabilities
}

\begin{abstract}
Intellectual disability is a significant limitation in the intellectual function and adaptive behavior of a person that appears before the age of 18 years. One of the adaptive behaviors is conceptual skill, which includes functional reading. For students with mild intellectual disabilities, the main purpose of functional reading is to get beneficial information for their daily lives. This skill is also important for self-adjustment and to live independently in their environment. The intervention to strengthen this skill is paraphrasing strategies that consist of three steps: reading, asking, and putting (RAP) the information in their own words. This strategy has been proven to improve reading comprehension in high school students with mild intellectual disabilities (Hua, WoodsGroves, Ford, \& Nobles, 2014; Feeney, 2012), but the implementation of this strategy on students with mild intellectual disabilities in junior high school is yet to be examined. Through this single subject experimental study, the researcher aims to see whether the RAP strategy is effective in improving functional reading comprehension for a student with a mild intellectual disability. The research was conducted in three stages: preparation, implementation, and data analysis. In the implementation stage, techniques for teaching the RAP strategy to the participant referred to the direct instruction stage. The results showed an improvement in the participant's functional reading comprehension before and after the intervention program. The participant was also able to maintain functional reading ability without guidance from the researcher.
\end{abstract}

Keywords: functional reading comprehension; mild intellectual disability; Read, Ask, Put strategy; single-case experimental design

\section{Introduction}

As social beings, humans are expected to adapt to their environment to survive. Therefore, people behave to meet the daily demands of their environment, which is called adaptive behavior (Harrison \& Oakland as cited in Woolf, 2006). The higher one's ability to behave in an adaptive manner, the more likely he or she can adjust to the demand of the situation (Bildt, Sytema, Kraijer, Sparrow, \& Minderaa, 2005). One thing related to the ability of people's adaptive behavior is their level of intelligence (Meyers, Nihira, \& Zetlin as cited in Bildt et al., 2005). This relevance is clearly seen in individuals with intellectual disabilities, in which the lower their intelligence level, the lower their ability to behave adaptively (Paskiewicz, 2009). This limitation in adaptive behavior also becomes a characteristic of intellectual disability. Hallahan and Kauffman (2012) define intellectual disability as a significant limitation in the intellectual function and adaptive behavior of a person that appears before the person is 18 years of age.

One part of adaptive behavior is conceptual skill, besides social and practical skill, which includes reading skill (Tassé, Schalock, Balboni, Bersani, Borthwick-Duffy, Spreat, Thissen, Widaman, \& Zhang, 2012). The ability to read and understand written or printed text is a part of social life, and if one lacks that ability then it is likely that he or she will experience obstacles in his or her social life (Luhmann as cited in Lundberg \& Reichenberg, 2013). Individuals who 
have a problem with reading will also find it difficult to live independently. They also find it difficult to perform daily activities that require reading, even simple ones (National Center for Education Statistics as cited in Mahlburg, 2013). Thus, it can be said that reading comprehension is not only required in the academic area, but also required in daily life (The National Assessment of Educational Progress as cited in Kirsch \& Guthrie, 1978).

The ability to read and to comprehend reading in social and daily life is referred to as functional reading (Wilson \& Barnes as cited in Gambrell \& Cleland, 1982). Functional reading ability is beneficial for individuals to obtain various information that is commonly encountered in everyday life, such as menus, recipes, drug labels, newspapers, forms, directions, and instructions. In other words, functional reading comprehension can support individuals in their daily life (Mumpuniarti, 2004; Gambrell \& Cleland, 1982). For students with mild intellectual disabilities, functional reading serves two main goals: the first is to read for protection, such as reading directions, and the second is to get information and instruction in their daily lives, such as reading job vacancies, advertising, and so on (Kirk \& Monroe as cited in Myreddi \& Narayan, 1998). Furthermore, functional reading ability is important for individuals to adjust to and live independently in their environment (Polloway \& Patton as cited in Myreddi \& Narayan, 1998).

Nevertheless, students with intellectual disabilities have difficulty in areas related to reading, including reading comprehension (Mahlburg, 2013). Conners (Gronna et al. as cited in Feeney, 2012) found that the reading ability of students with intellectual disabilities began to lag behind when they were between the ages of 7 and 10 years. They are generally able to master early reading skills with other students of their age, such as sight words, letter identification, and phonological awareness, but have difficulty mastering higher reading skills (Conners et al. as cited in Feeney, 2012). Gronna et al. (as cited in Feeney, 2012) found that junior high school students with mild intellectual disabilities can still develop their reading skills until tenth grade, although their development is generally slower than other nondisabled students. This indicates that students with mild intellectual disabilities can develop their reading skill, although they require more intensive instruction than other nondisabled students (Baker as cited in Hua, Woods-Groves, Ford, \& Nobles, 2014).

The intervention that can improve reading comprehension for students with mild intellectual disabilities is the Read, Ask, Put (RAP) strategy. This strategy was developed by Schumaker, Denton, and Deshler in 1984 (Hua et al., 2014). The RAP strategy consists of reading, asking themselves what they read - the main ideas and details or supporting words in the paragraphand paraphrasing it (Hagaman, Luschen, \& Reid, 2010). The RAP strategy has several advantages compared to other interventions: it can be used with students at all levels, elementary school, junior high school, or high school (Hagaman \& Reid, 2008) and with children who have learning difficulties and intellectual disabilities (Harvey, n.d.). It also can be used in large groups, small groups, or individually (Blume, 2010). In relation to children with mild intellectual disabilities, the RAP strategy is considered more advantageous as it focuses on teaching cognitive strategies to compensate for their cognitive deficits (Cain, Oakhill, \& Bryant, 2004; Ellis \& Lenz, 1987; dalam Hua, Woods-Groves, Ford, \& Nobles, 2014). For students with mild intellectual disabilities, the RAP strategy has been used successfully to improve their reading comprehension (Hua et al., 2014; Feeney, 2012). Therefore, this research examines the effectiveness of the RAP strategy in improving functional reading comprehension in a student with a mild intellectual disability. 
The participant in this study is a male student with a mild intellectual disability. His intellectual limitations mean his academic performance is far below his peers. His performance started to show decline when he was in fourth grade, but at that time he attended remedial lessons in which the teacher repeated the subject material. This helped him graduate from primary school and continue his study in junior high school. The participant is quite independent in terms of daily self-care; what stands out for this participant is his low ability to understand text. He can read fluently, but he is only able to grasp the concrete and explicit information conveyed in a text, so he lacks the full meaning of what he reads. The lack of reading comprehension makes him dependent on others to deal with situations that require reading comprehension, such as reading instructions, filling out forms, reading announcements, and so on. Therefore, it is important to provide interventions to improve his functional reading comprehension so he can remain independent in his daily life.

In this study, the levels of reading comprehension used are the literal level and the inferential level. The higher level, which is the evaluative level, requires people to analyze or evaluate the information they obtain from reading based on their knowledge or experience (McCormick; Rupley \& Blair; as cited in Basaraba, Yovanoff, \& Alonzo, 2012). As such, they are required to retain textual information in their working memory and access their knowledge or experience in long-term memory at the same time (Basaraba et al., 2012). The complex cognitive process rely on working memory, such as the evaluative level stated before, is a limitation for students with mild intellectual disabilities (Hallahan \& Kauffman as cited in Mangunsong, 2009). Therefore, the level of reading comprehension in this research is only the literal and inferential level, to suit the characteristics of students with mild intellectual disabilities. In the Read stage, the participant is asked to read the functional text. In the Ask stage, the participant is asked to identify details and the main ideas of a paragraph, which is similar to the literal stage. In the Put stage, the participant is required to summarize the information or draw a conclusion, which is similar to the inferential stage.

\section{Methods}

\section{Participant}

The participant in this study was a 14-year-old male student with a mild intellectual disability (IQ $=58$, Wechsler scale) who is currently enrolled as an eighth grade student at a non-inclusive junior high school. The participant was recruited when his case was handled by one of the school partners of the Professional Graduate Degree of Educational Psychology at the University of Indonesia. The researcher conducted initial data collection by presenting the participant with reading texts from Bahasa Indonesia school textbooks for second, third, and fourth grade elementary students. The participant's reading comprehension was found to be equal to a third grade elementary school student. Moreover, the participant can read fluently, but he is only able to grasp concrete and explicit information from a text, so he lacks the full meaning of what he reads.

\section{Research Design}

This study uses a single-subject design to observe the effect of an intervention program on a single participant (Gravetter \& Forzano, 2009). Specifically, the research design used in this study is the AB design. This design consists of baseline phase (A) followed by treatment phase 
(B). Phase $\mathrm{A}$ is a series of observations conducted under the same conditions (condition without treatment/intervention), which was later called the baseline phase. Phase B is the observation phase during the intervention and is later called the treatment phase (Gravetter \& Forzano, 2012). Through this design, researchers can identify a cause-and-effect relationship of the variables in the intervention by measuring the circumstances before and after the intervention (Gravetter \& Forzano, 2012). The effectiveness of the intervention can be interpreted through patterns of change before, during, and after intervention programs are provided (Gravetter \& Forzano, 2012).

\section{Measures}

This research uses a functional reading theme based on the participant's interest and ability, which is culinary (recipes). By considering the participant's interests, it is expected that improving his reading comprehension will also help him develop his skills. This study uses multiple choice questions, which are created based on literal and inferential reading comprehension to measure the participant's ability in functional reading comprehension before and after the intervention. There are 16 questions divided evenly between two different texts. Expert judgment of this measurement tool was provided by two teaching staff members from the Faculty of Psychology at the University of Indonesia and a special education teacher who teaches students with mild intellectual disabilities. The researcher also conducted a readability test on three adolescent students with mild intellectual disabilities. The researcher used a T-test analysis to determine the effectiveness of the intervention. Besides using quantitative data, the researcher also observes the participant's achievement of success indicators during each intervention session through visual inspection. The researcher uses scoring criteria to assess the participant's achievement. These scoring criteria are based on the level of reading comprehension, direct instruction stages, and consider the subject's ability compared to the initial data collection.

This intervention program targets the stages in the Read, Ask, Put strategy and adjusts to the reading comprehension level stated by Basaraba et al. (2012) and Lanier and Davis (1972) (i.e., literal level and inferential level). The instruments used in the intervention are functional texts and worksheets, and these instruments are also accompanied by visual representations such as worksheets with pictures and picture cards, as the use of visual representation for students with mild intellectual disabilities will allow them to understand the text more easily and reduce the load on their working memory (Feeney, 2012). It also helps them to identify, direct, and memorize important information from the text (Feeney, 2012; Bos \& Anders as cited in Roberts, 2008).

Table 1

Indicators of success and scoring criteria

\begin{tabular}{|c|c|c|}
\hline Indicator of Success & $\begin{array}{l}\text { Scoring Criteria } \\
\end{array}$ & Annotation \\
\hline \multirow[t]{3}{*}{$\begin{array}{l}\text { 1. Find the details in } \\
\text { the texts }\end{array}$} & $\begin{array}{l}\text { The participant mentions and } \\
\text { marks details in the functional } \\
\text { text }\end{array}$ & $\begin{array}{l}\text { Indicators: } \\
\text { - The participant mentions details in the text. } \\
\text { - The participant marks details in the text. } \\
1 \text { point for each achieved indicator. }\end{array}$ \\
\hline & & $\begin{array}{l}\text { Bonus score for each indicator: } \\
\text { - Score 0: The participant is able to answer with guided examples more than } \\
\text { once. } \\
\text { - Score 1: The participant is able to answer with little assistance. } \\
\text { - Score 2: The participant is able to answer independently }\end{array}$ \\
\hline & & Maximum score: 6 \\
\hline
\end{tabular}


Table 1, cont.

Indicators of success and scoring criteria

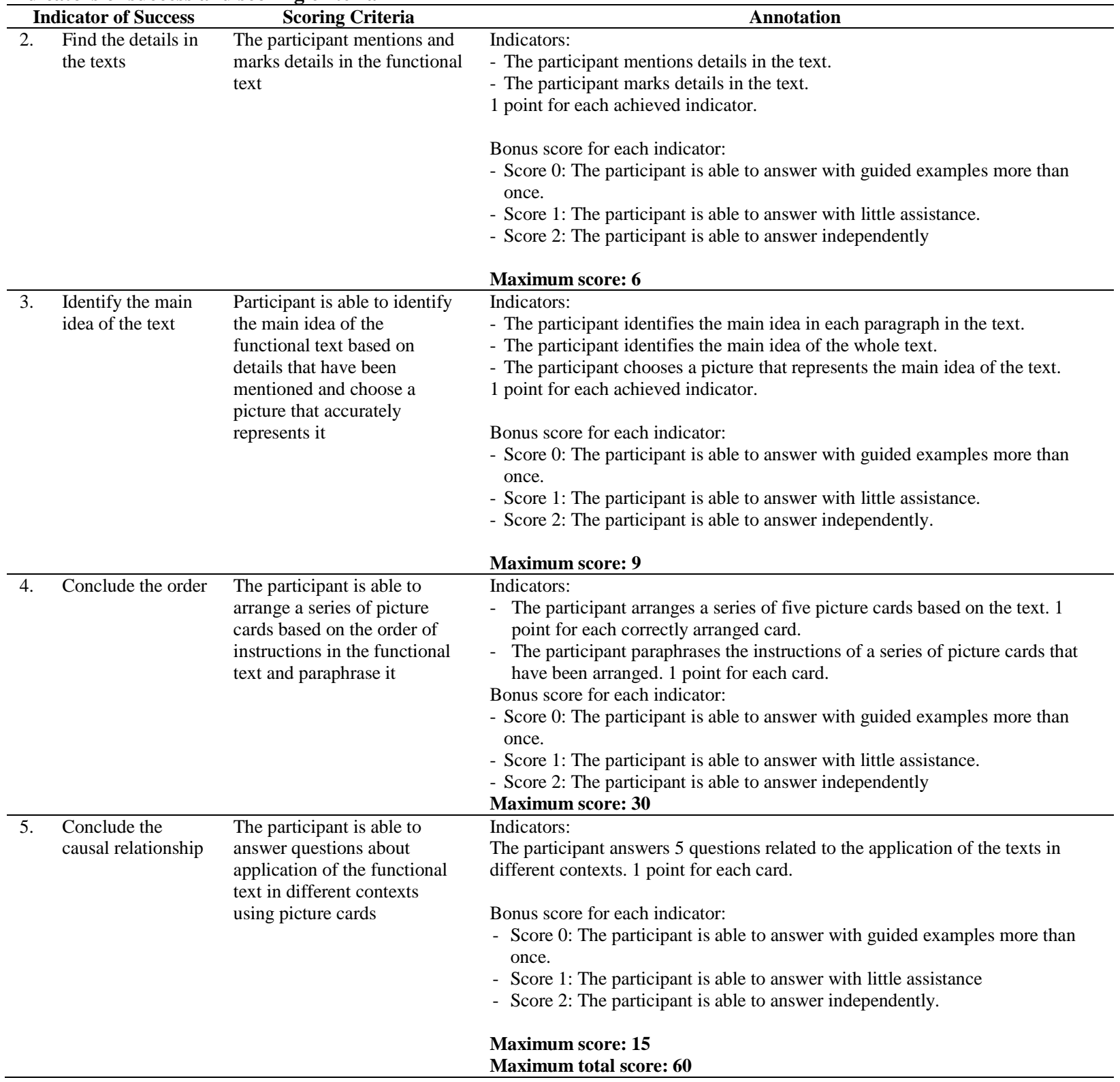

\section{Procedure}

This research was conducted in three stages: preparation, implementation, and data analysis. The preparation stage includes a needs analysis, literature review, designing the intervention program, and asking for the parents' and the school's consent for the student to be a research participant. The implementation stage is the intervention, which starts by providing a pre-test to measure the participant's initial ability in functional reading. This is followed by a presentation stage, in which the researcher teaches the RAP strategy with the functional reading texts presented as multiple short paragraphs and asks the participant to read each sentence. The next stage is the practice stage, which consists of two stages: guided practice and independent practice. 
In guided practice, the participant is guided and encouraged while doing the task, which is reduced if the participant shows an improvement in ability. The independent practice stage is done when the participant is able to do his tasks independently so that the role of the researcher is to monitor the process and give a few prompts only if needed (Magliaro, Lockee, \& Burton, 2005). The techniques for teaching the RAP strategy to the participant refer to the direct instruction stage as the implementation of a paraphrasing strategy conducted by Hua et al. (2014) and Feeney (2012). Each stage can be repeated if the participant has not mastered the material. The last stage is the post-test. There are two post-tests with a one-week interval between the first and second. The purpose of the second post-test is to find the extent to which the participant is able to maintain his ability without guidance from the researcher.

The intervention program was planned for seven meetings. In its implementation, the intervention program was held in nine meetings. The nine meetings consisted of one pre-program meeting, six meetings to implement the intervention program, and two meetings for the postprogram. The additional meeting is required because the participant needed more time to master the reading material at the inferential level.

Table 2.

Description of each session

\begin{tabular}{|c|c|c|}
\hline Session & $\begin{array}{l}\text { Purpose } \\
\end{array}$ & Activity \\
\hline Pre-program & $\begin{array}{l}\text { - Explain the intervention program and the } \\
\text { regulations that need to be followed (provide } \\
\text { contract study). } \\
\text { - Measure the participant's functional reading } \\
\text { comprehension before intervention. }\end{array}$ & $\begin{array}{l}\text { - Participant listens to the explanation of the intervention } \\
\text { program. } \\
\text { - Participant takes the pre-test. }\end{array}$ \\
\hline $\begin{array}{l}\text { Session 1: } \\
\text { Find the detail in the text }\end{array}$ & $\begin{array}{l}\text { Participant identifies and marks details in the } \\
\text { functional text. }\end{array}$ & $\begin{array}{l}\text { - Participant reads a functional text. } \\
\text { - Participant identifies details in the text. } \\
\text { - Participant marks details in the text. }\end{array}$ \\
\hline $\begin{array}{l}\text { Session 2: } \\
\text { Identify the main idea of } \\
\text { the text }\end{array}$ & $\begin{array}{l}\text { Participant mentions the main idea of the } \\
\text { functional text based on details that have been } \\
\text { identified and chooses a picture that accurately } \\
\text { represents the main idea of the functional text, }\end{array}$ & $\begin{array}{l}\text { - Participant reads a functional text. } \\
\text { - Participant marks important details (nouns) in the text. } \\
\text { - Participant identifies the main idea of each paragraph. } \\
\text { - Participant identifies the main idea of the text. } \\
\text { - Participant chooses a picture that represents the main } \\
\text { idea of the text. }\end{array}$ \\
\hline $\begin{array}{l}\text { Session 3: } \\
\text { Conclude the order }\end{array}$ & $\begin{array}{l}\text { Participant is able to arrange a series of picture } \\
\text { cards based on the order of the instructions of the } \\
\text { functional text and paraphrase it. }\end{array}$ & $\begin{array}{l}\text { - Participant reads a functional text. } \\
\text { - Participant is given a series of picture cards about the } \\
\text { instructions of the text. } \\
\text { - Participant arranges the picture cards based on the } \\
\text { instructions in the text. } \\
\text { - Participant is asked to paraphrase/retell the instructions } \\
\text { they have read with the assistance of picture cards. }\end{array}$ \\
\hline $\begin{array}{l}\text { Session } 4 \text { : } \\
\text { Conclude the causal } \\
\text { relationship }\end{array}$ & $\begin{array}{l}\text { Participant is able to answer questions about the } \\
\text { application of the functional text in different } \\
\text { contexts using the picture cards. }\end{array}$ & $\begin{array}{l}\text { - Participant reads a functional text. } \\
\text { - Participant is given picture cards about the details of } \\
\text { the text. } \\
\text { - Participant answers questions about the application of } \\
\text { instructions in the text in different contexts, then } \\
\text { answers them with the assistance of picture cards. }\end{array}$ \\
\hline Post-program 1 & $\begin{array}{l}\text { Measure the participant's functional reading } \\
\text { comprehension after intervention. }\end{array}$ & - Participant takes the first post-test. \\
\hline Post-program 2 & $\begin{array}{l}\text { Measure the extent to which the participant } \\
\text { maintains the ability of functional reading } \\
\text { comprehension without guidance from the } \\
\text { researcher. }\end{array}$ & - Participant takes the second post-test. \\
\hline
\end{tabular}

\section{Data Analysis}

The researcher compared the total scores from the participant's functional reading comprehension before and after the intervention. In addition, the researcher analyzed the qualitative data by observing the participant's progress in every session using indicators of 
success such as the observation guide (see Table 1); whether he had met the indicator of success was previously determined.

\section{Results}

The results of the research include qualitative analysis and quantitative analysis results. Table 3 illustrates the results of measurements obtained from the research.

Table 3.

Comparison of the participant's achievement in each session

\begin{tabular}{|c|c|c|c|}
\hline Purpose & Detail & Before Session & After Session \\
\hline $\begin{array}{l}\text { 1. Find the details in } \\
\text { the texts }\end{array}$ & $\begin{array}{l}\text { Indicators: } \\
\text { - The participant identifies details } \\
\text { in the text. } \\
\text { - The participant marks details in } \\
\text { the text. }\end{array}$ & $\begin{array}{l}\text { The participant is not able to find } \\
\text { details in the text } \\
\text { Score: } \mathbf{0}\end{array}$ & $\begin{array}{l}\text { - The participant is able to identify details } \\
\text { in the text. Score } \mathbf{3} \\
\text { - The participant marks details in the text } \\
\text { independently. } \\
\text { Score: } \mathbf{3}\end{array}$ \\
\hline Score & & $0 / 6(0 \%)$ & $6 / 6(100 \%)$ \\
\hline $\begin{array}{l}\text { 2. Identify main idea } \\
\text { of the text }\end{array}$ & $\begin{array}{l}\text { Indicators: } \\
\text {-The participant identifies the main } \\
\text { idea of each paragraph in the } \\
\text { text. } \\
\text {-The participant identifies the main } \\
\text { idea of the whole text. } \\
\text {-The participant chooses a picture } \\
\text { that represents the main idea of } \\
\text { the text. }\end{array}$ & $\begin{array}{l}\text { - The participant is not able to } \\
\text { identify the main idea of the } \\
\text { paragraphs and the whole text } \\
\text { Score: } \mathbf{0} \\
\text { - The participant is able to } \\
\text { choose a picture that } \\
\text { represents the main idea of the } \\
\text { text independently. } \\
\text { Score: } \mathbf{3}\end{array}$ & $\begin{array}{l}\text { - The participant is able to identify the } \\
\text { main idea of the paragraph with little } \\
\text { assistance. } \\
\text { Score: } \mathbf{2} \\
\text { - The participant is able to identify the } \\
\text { main idea of the text with little } \\
\text { assistance. } \\
\text { Score: } \mathbf{2} \\
\text { - The participant is able to choose a } \\
\text { picture that represents the main idea of } \\
\text { the text independently. } \\
\text { Score: } \mathbf{3}\end{array}$ \\
\hline Score & & $3(33.3 \%)$ & $7(77.8 \%)$ \\
\hline $\begin{array}{l}\text { 3. Conclude the } \\
\text { order }\end{array}$ & $\begin{array}{l}\text { Indicators: } \\
\text { - The participant arranges a } \\
\text { series of five picture cards } \\
\text { based on the text. } 1 \text { point for } \\
\text { each correctly arranged card. } \\
\text { - The participant paraphrases the } \\
\text { instructions of a series of } \\
\text { picture cards that have been } \\
\text { arranged. }\end{array}$ & $\begin{array}{l}\text { - The participant is able to } \\
\text { arrange } 1 \text { out of } 5 \text { picture cards } \\
\text { independently and correctly. } \\
\text { Score: } \mathbf{3} \\
\text { - The participant is able to } \\
\text { paraphrase } 1 \text { out of } 5 \text { picture } \\
\text { cards they arranged } \\
\text { independently. } \\
\text { Score: } \mathbf{3}\end{array}$ & $\begin{array}{l}\text { - The participant is able to arrange all } 5 \\
\text { picture cards independently and } \\
\text { correctly. Score: } \mathbf{1 5} \\
\text { - The participant is able to paraphrase } 4 \\
\text { out of } 5 \text { picture cards with little } \\
\text { assistance. Score: } \mathbf{1 4}\end{array}$ \\
\hline Score & & $6(20 \%)$ & $29(96.5 \%)$ \\
\hline $\begin{array}{l}\text { 4. Conclude the } \\
\text { causal relationship }\end{array}$ & $\begin{array}{l}\text { Indicator: } \\
\text { The participant is able to answer } \\
\text { questions about the application of } \\
\text { the functional text in different } \\
\text { contexts = using picture cards. }\end{array}$ & $\begin{array}{l}\text { - The participant is able to } \\
\text { answer } 3 \text { questions } \\
\text { independently. } \\
\text { Score: } 9 \\
\text { - The participant is not able to } \\
\text { answer } 2 \text { questions. } \\
\text { Score: } \mathbf{0}\end{array}$ & $\begin{array}{l}\text { - The participant is able to answer } 3 \\
\text { questions independently. } \\
\text { Score: } 9 \\
\text { - The participant is able to answer } 2 \\
\text { questions with little assistance. } \\
\text { Score: } 4\end{array}$ \\
\hline Score & & $9(60 \%)$ & $13(86.7 \%)$ \\
\hline Total score & & $18 / 60(30 \%)$ & $55 / 60(91.7 \%)$ \\
\hline Score difference & & $61.7 \%$ & \\
\hline
\end{tabular}

Maximum total score is 60 . Minimum score is 0 .

In the table above, we can see an improvement in the participant's scores of functional reading comprehension in all indicators after the intervention. Before the intervention was given, the participant got $30 \%$ correct answers. After the intervention, the percentage of the participant's achievement increased to $91.7 \%$. Table 4 displays the results of the statistical tests conducted using a T-test. 
Table 4.

Participant's achievement based on observation results and significance of change

$\%$ Participant's achievement of intervention success indicators

\begin{tabular}{lccccccc}
\hline & Session 1 & Session 2 & Session 3 & Session 4 & Mean & t & Sig (2-tailed) \\
\hline Before session & $0 \%$ & $33.3 \%$ & $20 \%$ & $60 \%$ & $28.33 \%$ & -3.788 & 0.032 \\
\hline After session & $100 \%$ & $77.8 \%$ & $96.5 \%$ & $86.7 \%$ & $90.25 \%$ & & \\
\hline
\end{tabular}

Based on the results of the statistical tests conducted using the T-test, obtained $t=-3.788$; sig (2tailed $)=0.032$. The result shows that $\mathrm{p}<0.05$. Therefore, it can be said that the improvement of a participant's functional reading comprehension increased significantly.

In addition, here are the results and comparison of the pre-test and post-tests total scores.

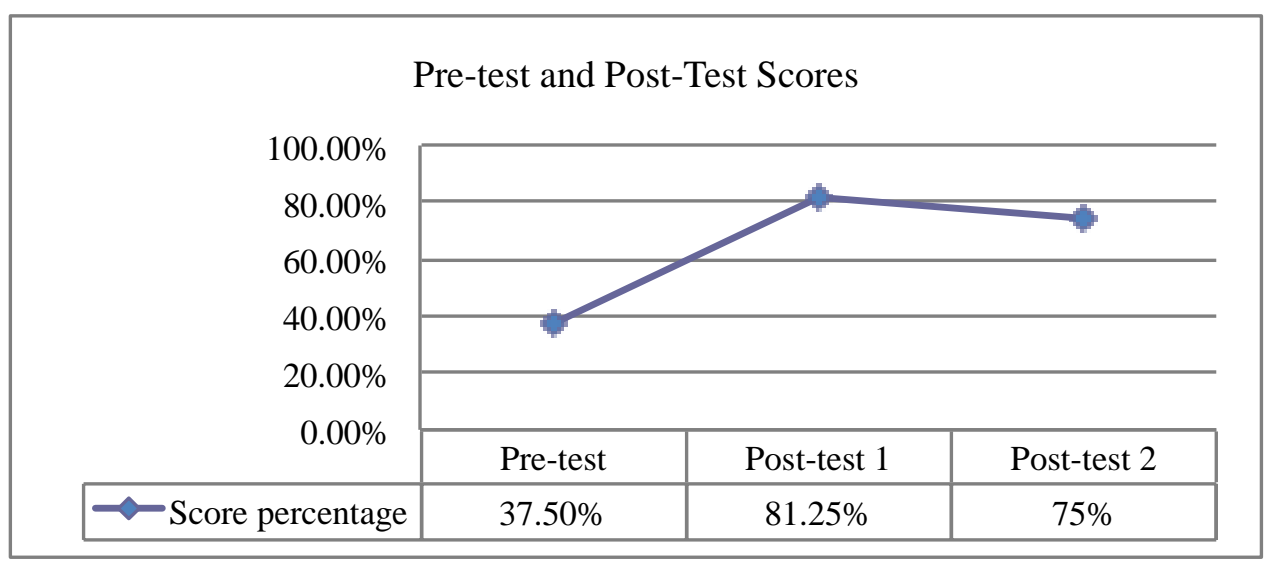

Figure 1. Functional reading comprehension test score percentage

As seen in the graph above, the result of the first post-test shows an increase of $43.75 \%$, which means the participant's functional reading comprehension was improved after the intervention. There's a slight difference of only one point between the first and the second post-test, which means that the participant was able to maintain his functional reading ability even without guidance from the researcher.

This research also found an improvement on the inferential level score. Before the intervention, the participant was only able to give one correct answer - or one point. After the intervention, the result of the first post-test shows that the participant's score increased to six points. Similar to the functional reading, there was a slight difference in the second post-test, but it was still higher than the pre-test score. 


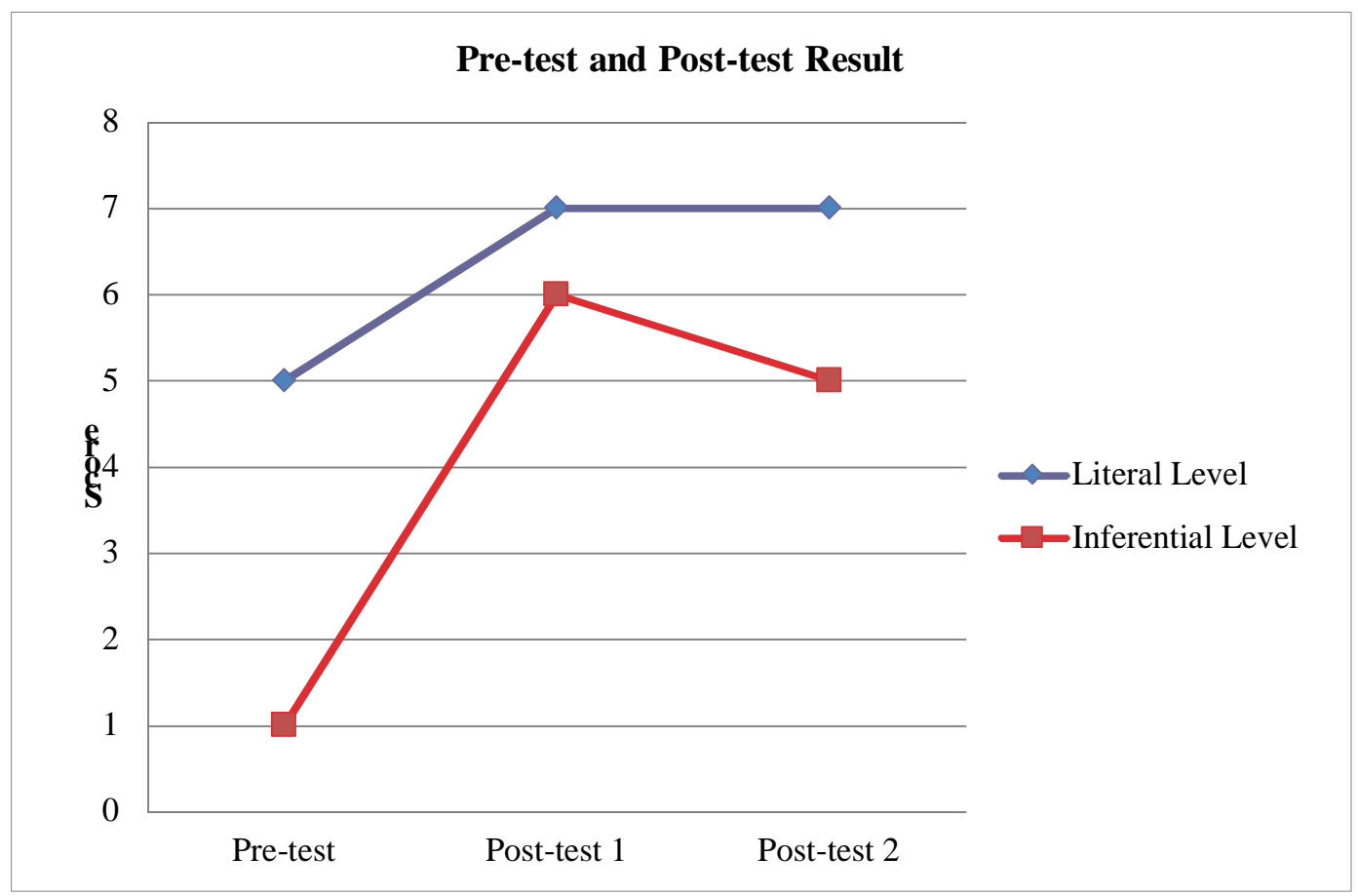

Figure 2. Comparison of participant's answers in each reading comprehension level

Based on the result above, both data trends show an improvement in all indicators after the RAP strategy was given. The participant was also able to maintain their ability without guidance from the researcher. Thus, the intervention program using the RAP strategy is effective to improve the participant's functional reading comprehension skill.

\section{Discussion}

The success of this intervention program was due to the implementation of the RAP strategy, which requires breaking the passage into short paragraphs to reduce the working memory of the student with a mild intellectual disability (Hua et al., 2014). It addressed the findings from a study aimed to improve reading comprehension in students with mild intellectual disabilities by using the story map method (Silmi, 2014); although the result shows that the participant's reading comprehension ability was improved, there was material that was too abstract to apply to students with mild intellectual disabilities. This research has proven that the participant understood the information more easily after the text was presented as multiple short paragraphs and required the participant to read each sentence. The RAP strategy also addressed the attention issues in students with mild intellectual disabilities. Hallahan and Kauffman (as cited in Mangunsong, 2009) said that students with mild intellectual disability often cannot allocate their attention properly. In the RAP strategy, this issue is tackled through the Ask stage - a stage that requires students to identify the details and main idea of a paragraph - so students did not have to focus on irrelevant things in the text (Hua et al., 2014). In this study, using the RAP strategy made the participant focus his attention on only important information in the text more easily. The participant was also able to identify the main idea of a paragraph and the correlation between paragraphs with less difficulty than before the intervention programs are provided. 
Another benefit of implementing the RAP strategy is it allows the researcher to ensure that the participant had mastered the current material before moving on to the next reading material. In the previous research about the implementation of the RAP strategy on a slow learner by Fransisca (2016), the result showed that at the end of the intervention program, the participant was able to understand the main idea of a paragraph but still had difficulty understanding the main idea of the whole text. A study conducted by Silmi (2014) on a student with mild intellectual abilities also showed that there was a reading component in the intervention program that did not improve until the end of the program. The RAP strategy tackled these issues by providing direct instruction to the participant. If the participant has not shown any improvement, the researcher would provide further explanation or repeat the process. Thus, during the evaluation at the end of each session, the participant is able to complete the given tasks independently or with a few guidance.

A study conducted by Conners (as cited in Feeney, 2012) found that students with mild intellectual disabilities had the same ability as nondisabled students in determining the main idea but showed a consistent lag behind nondisabled students at inferring or drawing a conclusion from the text. However, in the pre-test, the participant had not been able to identify the main idea in the text, although after the intervention he could identify the main idea from the text. In line with a statement from Hallahan and Kauffman (2012) that students with mild intellectual disabilities are categorized as educable; they are still able to learn this ability even if it takes longer.

The researcher also learned that repetition of the instruction is necessary for the participant to draw a conclusion in inferential level sessions because this level needed a more complex, cognitive process compared to the previous level - the literal level (Basaraba et al., 2012). This explains why the participant of this research needed more time to master the reading material at the inferential level. Moreover, students with mild intellectual disabilities had memory deficits (Mangunsong, 2009), which may be why the participant was less able to recall a material during the intervention. This issue was possibly reflected by the slightly decreasing score in the second post-test. Therefore, repetition became important in the learning process of this intervention program because eventually the participant was able to master all reading materials.

An internal factor that may greatly contribute to the success of the intervention program is the reading theme. In a study conducted by Febriani (2016), who used the RAP strategy with an underachiever student by presenting texts in various themes, it was found that the participant's functional reading ability fluctuated depending on the presented theme. Various themes were considered to influence participant's motivation to read during the intervention program. Besides that, it makes the benefits of understanding a text become superficial. Based on these findings, this study used a functional reading theme based on the participant's interest and ability (culinary), which may increase his motivation to keep up with the intervention program. It may also help him to have a better understanding of the text. This finding is supported by Klingner, Vaughn, \& Boardman (2007) who said that individuals' prior knowledge interacted with their interest in the text when they were reading (Klingner, Vaughn, \& Boardman, 2007). Prior knowledge also helps an individual to comprehend text in a better way (Best et al., 2008; Conners, 2003, as cited in Feeney, 2012). 
Future research should include direct practice to observe the participants' abilities to implement the reading comprehension skill in real life situation. Since this research only used functional reading materials that had been adjusted to the needs and interests of the participant, another suggestion is to find the effectiveness of the same intervention program with a different reading theme-adjusted to the needs of the participant. Giving homework after a session is also recommended to compensate for the participant's memory deficits. It is also recommended to measure the long-term effectiveness of this intervention program without any guidance from the researcher after a longer period of time.

\section{References}

Basaraba, D., Yovanoff, P., Alonzo, J. (2012). Examining the structure of reading comprehension: do literal, inferential, and evaluative comprehension truly exist?. Reading and writing, 26 (3), 349-379. DOI: 10.1007/s11145-012-9372-9

Bildt, S., Kraijer, D., Sparrow, S., Minderaa, R. (2005). Adaptive functioning and behaviour problems in relation to level of education in children and adolescents with intellectual disability. Journal of intellectual disability research, 49 (9), $672-$ 681. DOI: $10.1111 / \mathrm{j} .1365-2788.2005 .00711$.

Blume, C.D. (2010). RAP: A reading comprehension strategy for students with learning disabilities. Public access theses and dissertations from the college of education and human sciences, 64. Retrieved from http://digitalcommons.unl.edu/

Feeney, S.L. (2012). A comparison of two cognitive reading strategies on the comprehension of functional expository text by high school students with mild intellectual disabilities (Dissertation). Retrieved from ProQuest Dissertations and Theses database. (UMI No. 3538806)

Fransisca (2016). Increasing reading motivation and comprehension through the "Read, Ask, Put" (RAP) reading strategy in slow learner middle school student (Master's Theses). Universitas Indonesia, Depok, Indonesia.

Febriani, F. (2016). Enhancement of reading motivation through RAP (Read, Ask, Put) reading strategy teaching and reading diaries in underachiever student (Master's Theses). Universitas Indonesia, Depok, Indonesia.

Gambrell L.B., Cleland. C.J. (1982). Minimum competency testing: Guidelines for functional reading programs. Journal of reading, 25 (4), 342-344. Retrieved from www.jstor.org

Gravetter, F.J. \& Forzano, L.B. (2012). Research methods for the behavioral sciences (third edition). USA: Wadsworth Cengage Learning.

Hagaman, J.L., Reid, R. (2008). The effects of the paraphrasing strategy on the reading comprehension of middle school students at risk for failure in reading. Remedial and special education, 29 (222). DOI: 10.1177/0741932507311638

Hagaman, J.L., Luschen, K., Reid, R. (2010). The "RAP" on reading comprehension. Teaching exceptional children, 43 (1), $22-$ 29. Retrieved from tcx.sagepub.com.

Hallahan, D. P. \& Kauffman, J. M. (2006). Exceptional learners: introduction to special education (10 ${ }^{\text {th }}$ ed.). Boston: Pearson Education.

Hua, Y. Woods-Groves, S.W., Ford, J.W., Nobles, K.A. (2014). Effects of the paraphrasing strategy on expository reading comprehension of young adults with intellectual disability. Education and training in autism and developmental disabilities, 49 (3), 429-439.

Kirsch I., Guthrie, J.T. (1978). The concept and measurement of functional literacy. Reading research quarterly, 13 (4), $485-507$. Retrieved from www.jstor.org

Klingner, J.K., Vaughn, S., Boardman, A. (2007). Teaching reading comprehension to students with learning difficulties. New York: The Guilford Press.

Lanier, R.J., Davis, A.P. (1972). Developing comprehension through teacher-made questions. The reading teacher, 26 (2), $153-$ 157. Retrieved from www.jstor.org

Lundberg, I., Reichenberg, M. (2013). Developing reading comprehension among students with mild intellectual disability: An intervention study. Scandinavian journal of educational research, 57 (1), 89-100. DOI: 10.1080/00313831.2011.623179

Magliaro, S.G., Lockee, B.B., Burton, J.K. (2005). Direct instruction revisited: a key model for instructional technology. ETR\&D, 53 (4), 41-55. ISSN: 1042-1629

Mahlburg, R. (2013). Reading and students with intellectual disabilities: using the readers workshop model to provide balanced literacy instruction. Retrieved from www.lynchburg.edu

Mangunsong, F. (2014). Psikologi dan pendidikan anak berkebutuhan khusus. Depok: LPSP3 UI.

Mumpuniarti (2004). Teaching functional reading to the mildly retarded students through elected approach. Jurnal Rehabilitasi \& Remediasi, 52-63. ISSN: 0854-0020.

Myreddi, V.. Narayan, J. (1998). Functional academics for students with mental retardation: A guide for teachers. India: National Institute for the Mentally Handicapped. 
Paskiewicz, T.L. (2009). A Comparison of Adaptive Behavior Skills and IQ in Three Populations: Children with Learning Disabilities, Mental Retardation, and Autism (Dissertation). Retrieved from ProQuest Dissertations and Theses database. (UMI No. 3344403)

Roberts, G., Torgesen, J.K., Boardman, A., Scammacca, N. (2008). Evidence-based strategies for reading instruction of older students with learning disabilities. Learning disabilities research \& practice, 23 (2), 63-69. DOI: 10.1111/j.15405826.2008.00264.x

Silmi, H.A. (2014). Effectiveness of story map strategy to increase reading comprehension for student with mild intellectual disability (Master's Theses). Universitas Indonesia, Depok, Indonesia.

Tassé, M.J., Schalock, R.L, Balboni, G., Bersani, H., Borthwick-Duffy, S.A., Spreat, S., Thissen, D. Widaman, K.F., Zhang, D. (2012). The construct of adaptive behavior: its conceptualization, measurement, and use in the field of intellectual disability. American journal on intellectual and developmental disabilities, 117 (4), 291-303. DOI: 10.1352/19447558-117.4.291.

Woolf, S. (2006). Critical elements of adaptive behavior in promoting community independence for individuals diagnosed with developmental disabilities (Dissertation). Retrieved from ProQuest Dissertations and Theses database. (UMI No. 3239155) 